\title{
Shell Carbon Isotope Indicators of Metabolic Activity in the Deep-Sea Mussel Bathymodiolus childressi
}

P.M. Riekenberg ${ }^{1, *}$, R.S. Carney ${ }^{1}$, B. Fry ${ }^{2}$

${ }^{I}$ Department of Oceanography and Coastal Sciences, Louisiana State University, Baton Rouge, LA, 70803, USA

${ }^{2}$ Australian Rivers Institute, Griffith University, 170 Kessels Road QLD 4111, Australia

*Corresponding author: Tel.: +31 644994652

Present address: NIOZ Royal Netherlands Institute for Sea Research, Department of Marine Microbiology and Biogeochemistry, PO Box 59, 1790AB Den Burg

E-mail address: phrieken@gmail.com (P.M. Riekenberg)

Running page head: Metabolic carbon cold seep mussel

\begin{abstract}
:
The incorporation of metabolic carbon $\left(\mathrm{C}_{\mathrm{m}}\right)$ into shells of mollusks has been used as an indicator of animal condition and availability of food resources in estuarine and freshwater settings. This study examines $\mathrm{C}_{\mathrm{m}}$ in Bathymodiolus childressi, a marine cold seep mussel dependent on methanotrophic symbionts. As seeps develop, mature, and go quiescent, methane supply will vary and affect the amount of metabolic carbon deposited into the growing shell. $B$. childressi $(\mathrm{n}=136)$ were live-collected from two seep sites over a 17 year period in the Northern
\end{abstract}


Gulf of Mexico to investigate whether changes in $\mathrm{C}_{\mathrm{m}}$ were detectable between sites and across years. Significant differences in $\mathrm{C}_{\mathrm{m}}$ were observed between mussel populations at Brine Pool (15.4 $\pm 0.4 \%)$ and Bush Hill $(10.3 \pm 0.3 \%) . \mathrm{C}_{\mathrm{m}}$ also changed significantly within each site across year (Bush Hill 1991: 12.2 $\pm 0.5 \%, 1992: 17.3 \pm 0.8 \%$ ) and decadal time scales (Brine Pool 1989: $15.5 \pm 0.7 \%, 2006: 19.5 \pm 0.7 \%)$. These findings agree with previous studies that found mussel condition was higher at Brine Pool and correlate well with a trophic mixing model that indicated significantly higher methane source utilization at the Brine Pool (65 $1.1 \%)$ than at Bush Hill $(49 \pm 1.6 \%)$. Further development of this method should allow for assessment of $C_{m}$ in shell assemblages as an indicator of historical resource availability at both active and former cold seep sites.

Keywords: mytilid, methane, metabolic, B. childressi 


\section{Introduction}

Accumulation of mixed-species bivalve shells are a common feature of deep-water hydrocarbon seep communities (Callender and Powell, 2000; Heyl et al., 2007; Lessard-Pilon et al., 2010). These shells are present at both active and quiescent seeps and have the potential of providing material for environment characterization and temporal reconstructions. The mussel component of shell assemblages may reflect cessation or reduction of methane flux if the dominant mollusk is fully or partially dependent on methanotrophic symbionts (Callender and Powell, 2000; Powell et al., 1999). A more complete understanding of the potential cause of population death can be obtained from shell-based indicators of animal physiology. While data from shallower settings are relatively common (McConnaughey \& Gillikin 2008; Gillikin et al., 2009, Lartaud et al., 2010), long term physiological data sets that might bear on seep activity or from continental slope settings are rare.

Bathymodiolus is a common hydrocarbon seep and hydrothermal vent genus with relatively well-known biology whose shell material is abundant (Aharon et al., 1997; Miyazaki et al., 2010). Bathymodiolus childressi is a mytilid mussel dominant in upper continental slope seeps in the Gulf of Mexico as a genetically uniform meta-population (Carney et al., 2006). The species complex is more widely distributed in the Atlantic (Arrellano \& Young 2009, Arellano et al. 2014, Prouty et al. 2016) as is consistent with long-dispersion larvae. Symbiotic dependence on methanotrophic microbes has been well established (Dupperon et al., 2007, Assié et al., 2016). The functional capability for particle feeding has been shown in aquarium studies, and stable isotope data from field-collected specimens is consistent with an ancillary dependence on detrital material (Riekenberg et al., 2016). B. childressi have a functional gut that supports filter feeding (Page et al., 1990) of detrital material that can include both phytoplankton-derived material and 
free-living chemosynthetic bacteria that are present within cold seep habitats (Riekenberg et al., 2016).

Deepwater seeps in the northern Gulf of Mexico are not constant habitats for B. childressi. The rate and composition of methane seepage is different among sites and changes along with methane reservoir fluctuations in the underlying sediments (Bergquist et al., 2004; Bergquist et al., 2005; Solomon et al., 2008). As a result of this variation, B. childressi populations would be expected to be found in a range of physiological conditions that reflect variability in methane resource abundance. Previous studies have demonstrated clear between-site differences for mussel growth and condition indices (Nix et al., 1995; Smith et al., 2000), with Brine Pool more favorable than Bush Hill. But these studies have failed to address the cause of differences between the seeps, leading to speculation that resource availability $\left(\mathrm{CH}_{4}, \mathrm{O}_{2}\right)$ or exposure to hydrogen sulfide were the determining factors for condition and growth. Besides live assemblages, dead mussel assemblages consisting solely of remnant shells are common and assumed to be caused by the cessation of methane seepage if the dominant mollusk is fully or partially dependent on methanotrophic symbionts (Powell et al., 1999; Callender and Powell, 2000). A more complete understanding of the likely cause of population extinction at death assemblage sites requires development of shell-based indicators in living assemblages.

During calcification, mussels produce shell material that is a mixture of seawater dissolved inorganic carbon (DIC) and metabolic carbon $\left(\mathrm{C}_{\mathrm{m}}\right)$ derived from their diet (McConnaughey and Gillikin, 2008). The resulting carbon in the shell reflects the relative amounts of incorporation between these two sources that can be estimated by $\delta^{13} \mathrm{C}$ (McConnaughey et al., 1997). Typically in marine mollusks, the bulk of the precipitated carbon is derived from seawater DIC $\left(\delta^{13} \mathrm{C}\right.$ $\sim 1 \%$ ), but contribution of $\mathrm{C}_{\mathrm{m}}$ has been found to be as high as 35\% (Gillikin et al. 2009). Higher 
$\mathrm{C}_{\mathrm{m}}$ incorporation results in a lower $\delta^{13} \mathrm{C}$ value for the shell when the food being incorporated is depleted in comparison to seawater DIC ( -21.5\%, particulate organic matter; Wells and Rooker, 2009). In estuarine settings the incorporation of organic-derived carbon shifts shell $\delta^{13} \mathrm{C}$ values away from seawater DIC values resulting in shell material that is $\sim 3 \%$ lower for $\delta^{13} \mathrm{C}$ than seawater DIC (Lorrain et al., 2004; Gillikin et al., 2007; Fig. 1) given comparable incorporation of $\mathrm{C}_{\mathrm{m}}$. In cold seep settings the food sources for $B$. childressi have comparatively low $\delta^{13} \mathrm{C}$ values due to considerable dietary contribution from methane-derived carbon (both thermogenic -45.4\%o (Sassen et al., 2004) and biogenic $-63.8 \%$ (Sassen et al., 1999) and from particulate feeding on free living microbes (-31\%o; Demopoulos et al., 2010). Incorporation of these ${ }^{13} \mathrm{C}$ depleted site-specific resources is expected to cause lower shell $\delta^{13} \mathrm{C}$ values in $B$. childressi (Fig. 1).

Several factors contribute to the $\delta^{13} \mathrm{C}$ values found in mollusk shells including 1) variation of ambient seawater DIC associated with bottom waters, 2) availability of food resources, and 3) size effects caused by ontogenesis. 1) Wide $\delta^{13} \mathrm{C}$ variations have been observed for DIC within estuarine sites having moderate and variable salinity. This variability makes utilization of shell carbonates for seawater paleo-DIC reconstruction difficult and usually inappropriate (Wanamaker et al., 2007). However, in sites that have stable low (upper estuary) or high salinity (continental shelf) conditions, epifaunal species have been found to consistently precipitate seawater DIC in equilibrium to environmental conditions after accounting for incorporation of metabolic carbon (Hickson et al., 1999; Lorrain et al., 2004). 2) Increased availability of food has been observed to influence the $\delta^{13} \mathrm{C}$ in precipitated shells of Mytilus edulis and resulted in lower $\delta^{13} \mathrm{C}$ compared to animals raised on a low-ration diet (Lartaud et al., 2010). 3) As marine and freshwater mollusks grow, increased incorporation of isotopically light metabolic carbon 
into the shell is observed as growth slows. This size effect results in decreased shell $\delta^{13} \mathrm{C}$ values in larger animals (Krantz et al., 1987; Dettman et al., 1999; Gillikin et al., 2007; McConnaughey and Gillikin, 2008).

In this study we compared the incorporation of metabolic carbon derived from diet into the shell of B. childressi sampled from two distinctly different cold seep sites in the Northern Gulf of Mexico during 1989, 1991, 1992 and 2006. Our aim was to determine if there were quantifiable differences in the incorporation of metabolic carbon in sampled B. childressi caused by differences in methane resource abundance 1) between different cold seep sites, (2) within those sites across time, and 3) with shifts in dietary composition.

\section{Methods}

\section{Study site}

Mussels were collected from two seep sites Bush Hill (BH, Green Canyon (GC) lease block 185) and Brine Pool (BP, or GC lease block 233), located at 540-650 m depth on the continental shelf of the northern Gulf of Mexico. Bush Hill is an expulsion feature located along a seep-prone fault flanking a large salt diapir. This site consists of isolated mussel beds scattered over a topographically complex area of sediment, exposed authigenic carbonates, and methane hydrate mounds (MacDonald et al., 2003). Methane flux at the seafloor appears to be highly localized and methane originates from an underlying hydrate reservoir. The Brine Pool is a lower-relief feature in an area of extensive slope failures and has been characterized as a quiescent mud volcano (Joye et al., 2009). Most methane flux appears to come from the pool which is surrounded by a continuous bed of mussels. Samples were taken near the pool and at the 
outer edge of the fringing mussel bed at both the North and South ends of the pool. Further site description can be found in Riekenberg et al., (2016).

\section{Sample Processing}

Specimens were collected by the submersible Johnson SeaLink, preserved in 5\% seawater formalin and maintained in archival storage. Specimens were collected from Bush Hill in 1991 and 1992 and the Brine Pool in 1989, 1991, and 2006 as part of a previous study (Carney, 1994; MacAvoy et al., 2003). $\delta^{13} \mathrm{C}(\%)$ was measured for both shell and tissue of previously archived B. childressi specimens for 136 individuals from the two seep sites $(\mathrm{BH} n=68, \mathrm{BP} \mathrm{n}=68)$. Samples were pooled from multiple sample grabs across discrete patches within each site.

In 2010, archived mussel specimens were opened and washed in deionized water (DI) for up to 24 hours to dilute and remove seawater salt, sulfate, and unincorporated formalin. The specimens were then dissected, shell height measured, and tissue and shell were dried at $60^{\circ} \mathrm{C}$. Tissue samples were taken from the adductor muscle and shell samples were broken from the outer $1 \mathrm{~cm}$ edge of single valves, incorporating all calcified layers in these edge samples. Adductor tissue was powdered and prepared for CNS analysis as described in Fry (2007). Shell samples had the outer periostracum and any accreted authigenic carbonates physically removed and bare shell was ground into powder, treated with sodium hypochlorite for 12 hours to remove organic material within the shell (protein), rinsed copiously with DI, and then dried prior to analysis. The use of sodium hypochlorite for the removal of organic material (Weber and Woodhead, 1970) is a method routinely used with little to no observed effect on either the $\delta^{13} \mathrm{C}$ or $\delta^{18} \mathrm{O}$ of inorganic carbonate within the sample (Bell et al., 2009). Both shell and tissue $\delta^{13} \mathrm{C}$ values are reported versus Vienna PeeDee Belemnite with a 95\% confidence level for analyses. Shell samples were run in the same manner as tissue samples (i.e., by combustion at $1000^{\circ} \mathrm{C}$ ) 
with only carbon isotope values retained. For shell samples, sulfur and nitrogen yields were negligible reflecting a negligible remnant of organic matter after treatment. A previous comparison between the combustion method and acidification method for carbonates (Spótl and Vennemann, 2003) found similar yields for carbon and similar $\delta^{13} \mathrm{C}$ values $( \pm 0.1 \%$ SD) between the two methods. We also performed combustion/acidification comparisons with shell material confirming similar results for both methods.

\section{Mixing model and corrections}

The model used for calculating the incorporation of metabolic carbon into shell material was a 2-source model from McConnaughey et al. (1997). The following equation was solved for $\mathrm{C}_{\mathrm{m}}$, the $\%$ contribution of metabolic carbon:

$$
\mathrm{C}_{\mathrm{m}}=\left(\delta^{13} \mathrm{C}_{\text {shell }}-\Delta-\delta^{13} \mathrm{C}_{\text {DIC }}\right) /\left(\delta^{13} \mathrm{C}_{\text {tissue }}-\delta^{13} \mathrm{C}_{\text {DIC }}\right) \times 100
$$

where $\delta^{13} \mathrm{C}_{\text {shell }}$ is the $\delta^{13} \mathrm{C}$ for the shell of each mussel, $\Delta$ is the correction for fractionation during precipitation of calcite and aragonite, $\delta^{13} \mathrm{C}_{\mathrm{tissue}}$ is the formalin-corrected tissue $\delta^{13} \mathrm{C}$ for each individual mussel (Riekenberg et al., 2016), and $\delta^{13} \mathrm{C}_{\mathrm{DIC}}$ is the value of Gulf of Mexico bottom seawater $(0.69 \%$ ) measured at Bush Hill previously $(\mathrm{Fu}, 1998) . \Delta$ represents the fractionation between shell and tissue $\mathrm{HCO}_{3}{ }^{-}$if carbonate precipitates in isotopic equilibrium with tissue $\mathrm{HCO}_{3}{ }^{-}$. The equilibrium fractionations for calcite and aragonite that were used are 1\%o and 2.7\%o (Romanek et al 1992). These fractionations were used in combination with x-ray diffraction measurements for a subset of shells within each site to estimate the resulting $\Delta$ using a 2-source mixing model to account for the relative composition of aragonite and calcite in the shells.

There were 2 types of small corrections made to the measured isotope data in the process of calculating $\mathrm{C}_{\mathrm{m}}$. Corrections and their magnitudes were as follows: 1) formalin incorporation into mussel tissue had a $2.5 \%$ range across tissue values that resulted in a correction for $\mathrm{C}_{\mathrm{m}}$ from 
-0.2 to $0.2 \%$ and 2 ) correction for the fractionation during precipitation of calcite and aragonite $\left(0.2 \% o \delta^{13} \mathrm{C}\right.$ range in the shell, correction for $\mathrm{C}_{\mathrm{m}}$ ranging from 0.25 to $\left.0.5 \%\right)$. Further detail about the formalin correction can be found in Riekenberg et al., (2016). Ratios of calcite/aragonite composition were measured by X-ray diffraction performed on a subset of mussel shells from each site (BP 35/65 \%calcite/\%aragonite, $\Delta=2.3 \%$; $\mathrm{BH} 25 / 75 \Delta=2.1 \%$ ). We report $\mathrm{C}_{\mathrm{m}}$ as finalized values that incorporate two corrections (formalin and carbonate type). We also investigated an additional method that corrected for vital effect due to size, using a linear relationship between $\delta^{13} \mathrm{C}_{\text {shell }}$ and shell height for both sites to remove the increased contribution to $C_{m}$ resulting from increased size (additional detail in Supplemental 1). Both methods (with and without size correction) gave the same patterns of significant differences detected between or within sites. This was likely due to similar size ranges being included in all analyses and statistical comparisons (additional detail in Supplemental 2). To ensure a comparison across a comparable size range among mussels at each site, only mussels with a shell height between 4.4 and $21 \mathrm{~mm}$ were included in the analyses in this study $(\mathrm{n}=136)$. This excluded larger mussels (>21 mm) that were present at the Brine Pool that were not represented at Bush Hill. We report $\mathrm{C}_{\mathrm{m}}$ without size correction here in the main text; size-corrected values are given in Supplement 1.

$\mathrm{C}_{\mathrm{m}}$ and contribution of methane resources to diet were determined for of 136 livecollected individuals from both seeps and a paired T-test was used to compare both $\mathrm{C}_{\mathrm{m}}$ and methane contribution to diet between sites. The contribution of methane resources to diet were calculated using a 4-source mixing model incorporating carbon, nitrogen and sulfur stable isotope values derived from mussel tissue and then accounting for both methane-derived and detrital resources within each cold seep site (Riekenberg et al. 2016). At the Brine Pool ( $n=68)$, 
sample size was sufficient to allow for comparison of $C_{m}$ among years $(1989 n=25,1991 n=$ $11,2006 \mathrm{n}=32)$ using a one-way analysis of variance. At Bush Hill $(\mathrm{n}=68)$, there was only sufficient replication within all sites sampled (Bed 1: $\mathrm{n}=28$, Bed 1A: $\mathrm{n}=21$, Bed 2: $\mathrm{n}=19$ ) for a paired T-test among years $(1991: \mathrm{n}=17$, and 1992: $\mathrm{n}=11)$ for Bed 1 .

\section{Results}

\section{Shell and tissue $\delta^{13} \mathrm{C}$ values between sites}

$\delta^{13} \mathrm{C}_{\text {shell }}$ values were considerably lower at the Brine Pool compared to Bush Hill (-8.7 \pm $0.3 \%$ and $-2.4 \pm 0.2 \%$, respectively; Figs. $1 \& 2$ ). $\delta^{13} \mathrm{C}_{\text {tissue }}$ values are also lower at the Brine Pool than compared to Bush Hill (-64.1 $\pm 0.7 \%$ and $-38.8 \pm 0.3 \%$, respectively; Figs. $1 \& 2)$ predominately due to the different sources of methane available at each site (biogenic at Brine Pool vs. thermogenic at Bush Hill). Tissue values fell on either side of the measured $\delta^{13} \mathrm{C}$ value for formalin used for archival preservation (-44.1\%; Dashed line, Fig. 2).

\section{$C_{m}$ comparisons between whole site populations}

$\mathrm{C}_{\mathrm{m}}$ at the Brine Pool was significantly higher than at Bush Hill (BP 17.7 $\pm 0.5 \%, \mathrm{BH}$ $13.7 \pm 0.4 \% ; \mathrm{T}_{129}=6.4, p<0.001$, Fig. 3). There were also temporal differences in $\mathrm{C}_{\mathrm{m}}$ values within sites (Fig. 4). $C_{m}$ was significantly higher for the Brine Pool sampling in 2006 than either the 1989 or 1991 sampling $(19.5 \pm 0.7 \%, 15.5 \pm 0.7 \%$, and $17.5 \pm 0.9 \%$, respectively; ANOVA: $\left.\mathrm{F}_{2,67}=8.7, p<0.001\right)$. At Bush Hill, samples were analyzed for 1991(n=17) and $1992(\mathrm{n}=11), \mathrm{C}_{\mathrm{m}}$ was significantly higher in 1992 than in $1991\left(17.3 \pm 0.8 \%, 12.2 \pm 0.5 \%\right.$, respectively; T-test: $\mathrm{T}_{26}=-$ 5.8, $p=<0.001$; Fig. 4).

\section{$\mathrm{C}_{\mathrm{m}}$, shell height, and methane contribution to diet between sites}

Average shell height was comparable between both sites, with BP being slightly larger than at BH (13.6 $\pm 0.5 \mathrm{~mm}$ vs $12.3 \pm 0.5 \mathrm{~mm}$, respectively; Fig. $2 \& 3$, Supplemental 2). Higher 
$\mathrm{C}_{\mathrm{m}}$ at the Brine Pool site correlated with increased utilization of methane resources within the populations at both sites (\% methane resources used; BP $64.9 \pm 1.1 \%$, BH $49.1 \pm 1.6 \%$; T-test: $\mathrm{T}_{121}=8.2, p<0.001$, Fig. 5) as calculated via a 4 source trophic mixing model using CNS stable isotopes from mussel tissue (Riekenberg et al., 2016). Mussels with the highest $C_{m}$ (circled data points for each site; Fig. 5) occurred at both sites when the diet of the mussels consisted of a mixture of detrital sources (phytoplankton and sulfur oxidizing microbes) and methane sources.

\section{Discussion}

\section{Comparing estuarine and cold seep $C_{m}$}

This is the first time that $\mathrm{C}_{\mathrm{m}}$ has been applied to a large population of cold seep mussels sampled across space and time. B. childressi had clear differences in the incorporation of $\mathrm{C}_{\mathrm{m}}$ into the shell both between cold seep sites and across years within sites. As a result of $B$. childressi having predominately relied on methanotrophic symbionts to oxidize methane as a food source, differences in $\mathrm{C}_{\mathrm{m}}$ are likely to be driven by the relative availability of methane within each cold seep site. Lower $\mathrm{C}_{\mathrm{m}}$ would be expected in periods of reduced methane availability or temporary cessation of seepage while increased $C_{m}$ would be expected from periods of abundant methane availability. The bulk of carbon precipitated into the mollusk shell is sourced from ambient seawater DIC, but a significant amount of metabolic carbon is simultaneously deposited. Incorporation of extremely $\delta^{13} \mathrm{C}$-depleted carbon derived from methane leaves the $\delta^{13} \mathrm{C}_{\text {shell }}$ of $B$. childressi significantly lower (Lietard and Pierre, 2009) than mollusks that rely solely on phytodetritus (Fig. 1) given comparable $\mathrm{C}_{\mathrm{m}}$. This net result from incorporation of metabolic carbon with considerably lower $\delta^{13} \mathrm{C}$ is greater resolution for $\mathrm{C}_{\mathrm{m}}$ in species with methanotrophic symbionts. Increased resolution allows a greater degree of confidence in the observed differences for $\mathrm{C}_{\mathrm{m}}$ in cold seep mussels when compared to freshwater or estuarine mussels (Lorrain et al., 
2004; Gillikin et al., 2007; McConnaughey and Gillikin, 2008; Gillikin et al., 2009; Lartaud et al., 2010). Increased spread in $\delta^{13} \mathrm{C}$ values between dietary resources and seawater DIC may be responsible for the increased range for $\mathrm{C}_{\mathrm{m}}(8-26 \%)$ found for $B$. childressi versus other species that were previously examined (7-15\%, (McConnaughey and Gillikin, 2008). However, this range falls well short of previously observed maximum incorporations for $\mathrm{C}_{\mathrm{m}}$ (35 and 37\%, (Gillikin et al., 2009; Gillikin et al., 2007).

\section{$\mathbf{C}_{\mathrm{m}}$ between sites}

B. childressi sampled at Bush Hill had both a lower $\mathrm{C}_{\mathrm{m}}$ and a smaller $\mathrm{C}_{\mathrm{m}}$ range than that found at the Brine Pool (Fig. 3). Decreased $\mathrm{C}_{\mathrm{m}}$ indicates lower incorporation of metabolic carbon and indicated that food (predominately methane, Fig. 5) was less available at Bush Hill than within the Brine Pool. The smaller range in $\mathrm{C}_{\mathrm{m}}$ at Bush Hill indicates comparatively less variation in the availability of food than at the Brine Pool. These findings correspond with lower utilization of methane resources indicated through use of a 4 source trophic mixing model (Riekenberg et al., 2016) and previous work that found mussel condition and growth was poorer at the Bush Hill site (Nix et al., 1995; Smith et al., 2000). A comparison between previously reported growth rates and $\mathrm{C}_{\mathrm{m}}$ for both sites revealed a positive relationship that indicated zero growth is likely to occur around $13.4 \%$ (y-intercept, Fig. 6). It appears that methane availability is more limited and less variable at the Bush Hill site. At the Brine Pool methane is generally more available and occasionally plentiful as indicated by the larger variability and increased range indicated in $\mathrm{C}_{\mathrm{m}}$. Alternatively, increased variability could be the result of elevated metabolic cost required for supplementing their diet with particulate feeding. Animals with the highest $\mathrm{C}_{\mathrm{m}}$ observed within both sites also have a diet with a decreased portion of methane derived sources (circled area, Fig. 5) indicating increased utilization of detrital materials. Any 
potential effects on $\mathrm{C}_{\mathrm{m}}$ from feeding strategy are unlikely to be sufficiently resolved from this data set but may provide an interesting avenue for future research. With this acknowledgement, it will be assumed that increased $C_{m}$ reflects increased resource availability for the remainder of this discussion.

\section{$C_{m}$ across time}

Brine Pool mussels recorded comparable $\mathrm{C}_{\mathrm{m}}$ in both 1989 and $1991(15.5 \pm 0.9 \%, 17.5 \pm$ $0.9 \%$, respectively), but in the 2006 sampling $C_{m}$ increased significantly $(19.5 \pm 0.7 \%)$ indicating an increased availability of food resources within that time period (17 years; Fig.4). Within Bush Hill $\mathrm{C}_{\mathrm{m}}$ increased from 1991 to 1992 (12.2 $\pm 0.5 \%, 17.3 \pm 0.8 \%$, respectively; Fig. 4) indicating a relatively sudden increase in available resources within the site across a much shorter time period (a single year). Differences in $\mathrm{C}_{\mathrm{m}}$ across both decadal and yearly time scales demonstrate that this method has potential to reconstruct the relative availability of methane resources across a range of time periods within a seep site or assemblage of dead mussel shells.

\section{Size-related metabolism and $\delta^{13} C_{\text {tissue }}$}

B. childressi displayed a clear size effect with decreased $\delta^{13} \mathrm{C}_{\text {shell }}$ values found with increased shell height at both study sites (Fig. 2). This ontogenic trend has been previously well described through linear regression (Gillikin et al., 2009) and has been found in a wide variety of mollusks (Krantz et al., 1987; Dettman et al., 1999; Gillikin et al., 2007; McConnaughey and Gillikin, 2008). In this study the size effect was found to be similar at both sites (see Supplement 1).

\section{DIC of bottom water}

This study uses a value of $0.69 \%$ for bottom water $\delta^{13} \mathrm{C}_{\text {DIC }}$ sampled just above the sediment water interface at Bush Hill during a separate study (Fu, 1998) for both sites. The range of variability in offshore oceanic bottom water $\delta^{13} \mathrm{C}$ DIC is typically much smaller ( $\sim 0.1$ to $0.3 \%$ ) 
offshore than in most coastal settings due to the lack of freshwater influence in deep ocean waters (McCorkle and Keigwin, 1994; Quay et al., 2003). The $\delta^{13} C_{\text {DIC }}$ of seep sediment porewaters do show strong isotope variations becoming increasingly ${ }^{13} \mathrm{C}$-depleted as sediment depth increases (e.g. - $11.1 \%$ at $2 \mathrm{~cm}$ depth; (Fu, 1998). Thus, there is potential for the incorporation of a substantially more ${ }^{13} \mathrm{C}$-depleted DIC from porewater during high flux rates of methane, but utilization of porewater DIC within mussel seep communities has been previously observed to be limited (Feng et al. 2015). If this potential source were substantially confounding, it would be be most evident within mussels receiving the highest exposure to methane flux. Because the bulk of the contribution to $\delta^{13} \mathrm{C}_{\text {shell }}$ comes from the ambient seawater DIC, incorporation of substantially depleted DIC would be expected to have clear and significant patterns that vary with methane availability (Fig. 7). No such significant patterns of decreased $\delta^{13} \mathrm{C}_{\text {shell }}$ with increased methane contribution to diet are evident in the data presented (BP $\mathrm{R}^{2}=0.08 ; \mathrm{BH} \mathrm{R}^{2}=0.03$, Fig. 7). The lack of a clear trend is likely due to $B$. childressi both being mobile and inhabiting an epifaunal position in mussel beds that allow for reliable access to bottom water DIC. Future studies should aim to better constrain ambient seawater DIC values during sampling if possible, but this was not feasible for the current study due to our use of archived historical samples.

\section{Implications}

Overall, the shells of $B$. childressi appear to reliably record changes in methane availability between different sites and across time periods. $\mathrm{C}_{\mathrm{m}}$ values found at each site in this study were comparable to previous direct assessments of mussel condition at each site and correlate well with a trophic mixing model for methane contribution to diet. These findings indicate that the use of shells as indicators of resource availability within mussel-dominated cold seep sites may allow 
for additional historical site information where live mussels are not available but death assemblages occur. This method has potential application where there is interest in reconstructing the historical availability of methane within active, quiescent, or geological cold seep sites (Lietard and Pierre, 2008; Lietard and Pierre, 2009; Landman et al., 2012; Ambrose et al., 2015). Ideally the record of $\mathrm{C}_{\mathrm{m}}$ that may be found in death assemblages (remnant shells) will determine if local extinctions were caused by termination of methane-flux or other factors. Both carbonate and protein (periostracum and organic matter) is preserved in shell material and can be used for the carbon isotope analysis needed for reconstruction of $\mathrm{C}_{\mathrm{m}}$ and seep histories (Cobabe \& Ptak 1999; Ellis et al. 2014). To make such inquiry possible, future research with livecollected mussels should examine the across-shell time record of $\mathrm{C}_{\mathrm{m}}$ incorporation as well as attempting to resolve any uncertainty about site seawater $\delta^{13} \mathrm{C}_{\mathrm{DIC}}$.

\section{LITERATURE CITED}

Aharon P., Schwarcz H.P., Roberts H.H., 1997. Radiometric dating of submarine hydrocarbon seeps in the Gulf of Mexico. GSA Bulletin 109 (5): 568-579.

Ambrose, W.G., Jr., Panieri, G., Schneider, A., Plaza-Faverola, A., Carroll, M.L., Åström, E.K.L., Locke, W.L.V., Carroll, J., 2015. Bivalve shell horizons in seafloor pockmarks of the last glacial-interglacial transition: A thousand years of methane emissions in the Arctic Ocean. Geochemistry, Geophysics, Geosystems 16 (12), 4108-4129. Arellano S.M., Van Gaest A.L., Johnson S.B., Vrijenhoek R.C., Young C.M., 2014. Larvae from deep-sea methane seeps disperse in surface waters. Proceedings of the Royal Society B: Biological Sciences 281.

Arellano S. M., Young C. M., 2009. Spawning, development, and the duration of larval life in a deep-sea cold-seep mussel. Biological Bulletin 216:149-162.

Assié A., Borowski C., van der Heijden K., Raggi L., Geier B., Leisch N., Schimak M.P., Dubilier N., Petersen J.M., 2016. A specific and widespread association between deep-sea 
bathymodiolus mussels and a novel family of epsilonproteobacteria. Environmental Microbiology Reports 8, 805-813.

Bell, L.S., Thorp, J.A.L., Elkerton, A., 2009. The sinking of the Mary Rose warship: a medieval mystery solved? Journal of Archaeological Science 36, 166-173.

Bergquist, D.C., Fleckenstein, C., Knisel, J., Begley, B., MacDonald, I.R., Fisher, C.R., 2005. Variations in seep mussel bed communities along physical and chemical environmental gradients. Marine Ecology Progress Series 293, 99-108.

Bergquist, D.C., Fleckenstein, C., Szalai, E., Knisel, J., Fisher, C.R., 2004. Environment drives physiological variability in the cold seep mussel Bathymodiolus childressi. Limnology and Oceanography 49 (3), 706-715.

Callender, R., Powell, E.N., 2000. Long-term history of chemoautotrophic clam-dominated faunas of petroleum seeps in the Northwestern Gulf of Mexico. Facies 43 (1), 177-204.

Carney, R.S., 1994. Consideration of the oasis analogy for chemosynthetic communities at Gulf of Mexico hydrocarbon vents. Geo-Marine Letters 14 (2), 149-159.

Carney, S.L., Formica, M.I., Divatia, H., Nelson, K., Fisher, C.R., Schaffer, S.W., 2006. Population structure of the mussel "Bathymodiolus" childressi from Gulf of Mexico hydrocarbon seeps. Deep-Sea Research Oceanography, A 53, 1061-1072.

Cobabe, E.A., Ptak, A.J., 1999. Comparison of in situ mineral-associated lipid compositions in modern invertebrate skeletons: preliminary evidence of dietary and environmental influence. Paleobiology 25 (2), 201-211.

Demopoulos, A.J., Gualtieri, D., Kovacs, K., 2010. Food-web structure of seep sediment macrobenthos from the Gulf of Mexico. Deep Sea Research II 57, 1972-1981.

Dettman, D.L., Reische, A.K., Lohmann, K.C., 1999. Controls on the stable isotope composition of seasonal growth bands in aragonitic fresh-water bivalves (Unionidae). Geochimica et Cosmochimica Acta 63 (7), 1049-1057.

Duperron, S., Sibuet, M., MacGregor, B.J., Kuypers, M.M.M., Fisher, C.R., Dubilier, N., 2007. Diversity, relative abundance and metabolic potential of bacterial endosymbionts in three Bathymodiolus mussel species from cold seeps in the Gulf of Mexico. Environmental Microbiology 9, 1423-1438. 
Ellis, G.S., Herbert, G., Hollander, D. 2014. Reconstructing carbon sources in a dynamic estuarine ecosystem using oyster amino acid $\delta^{13} \mathrm{C}$ values from shell and tissue. Journal of Shellfish Research 33 (1), 217-225.

Feng, D., Cheng, M., Kiel, Steffen, Qiu, J.W., Yang, Q., Zhou, H., Peng, Y., Chen, D. 2015. Using Bathymodiolus tissue stable isotope carbon, nitrogen, and sulfur isotopes to infer biogeochemical process at a cold seep in the South China Sea. Deep Sea Research Part 1: Oceanographic Research Papers 104, 52-59.

Fry, B., 2007. Coupled N, C and S stable isotope measurements using a dual-column gas chromatography system. Rapid Communications in Mass Spectrometry 21 (5), 750-756. Fu, B., 1998. A study of pore fluids and barite deposits from hydrocarbon seeps: deepwater Gulf of Mexico, Lousiana State University, Baton Rouge, Louisiana.

Gillikin, D.P., Hutchinson, K.A., Kumai, Y., 2009. Ontogenic increase of metabolic carbon in freshwater mussel shells (Pyganodon cataracta). Journal of Geophysical Research:

Biogeosciences 114 (G1), n/a-n/a.

Gillikin, D.P., Lorrain, A., Meng, L., Dehairs, F., 2007. A large metabolic carbon contribution to the $\delta^{13} \mathrm{C}$ record in marine aragonitic bivalve shells. Geochimica et Cosmochimica Acta 71 (12), 2936-2946.

Heyl, T.P., Gilhooly, W.P., Chambers, R.M., Gilchrist, G.W., Macko, S.A., Ruppel, C.D., Van Dover, C.L., 2007. Charateristics of vesicomyid clams and their environment at the Blake Ridge cold seep, South Carolina, USA. Marine Ecology Progress Series 339, 169-184.

Hickson, J.A., Johnson, A.L.A., Heaton, T.H.E., Balson, P.S., 1999. The shell of the Queen Scallop Aequipecten opercularis $(L$.) as a promising tool for palaeoenvironmental reconstruction: evidence and reasons for equilibrium stable-isotope incorporation. Palaeogeography,

Palaeoclimatology, Palaeoecology 154 (4), 325-337.

Joye, S.B., Samarkin, V.A., Orcutt, B.N., MacDonald, I.R., Hinrichs, K., Elvert, M., Teske, A.P., Lloyd, K.G., Lever, M.A., Montoya, J.P., Meile, C.D., 2009. Metabolic variability in seafloor brines revealed by carbon and sulphur dynamics. Nature Geosci 2 (5), 349-354.

Krantz, D.E., Williams, D.F., Jones, D.S., 1987. Ecological and paleoenvironmental information using stable isotope profiles from living and fossil molluscs. Palaeogeography, Palaeoclimatology, Palaeoecology 58 (3), 249-266. 
Landman, N.H., Cochran, J.K., Larson, N.L., Brezina, J., Garb, M.P., Harries, P.J., 2012. Methane seeps as ammonite habitats in the U.S. Western Interior Seaway revealed by isotopic analyses of well-preserved shell material. Geology 40 (6), 507-510.

Lartaud, F., Emmanuel, L., de Rafelis, M., Pouvreau, S., Renard, M., 2010. Influence of food supply on the $\delta^{13} \mathrm{C}$ signature of mollusc shells: implications for palaeoenvironmental reconstitutions. Geo-Marine Letters 30 (1), 23-34.

Lessard-Pilon, S., Porter, M.D., Cordes, E.E., MacDonald, I., Fisher, C.R., 2010. Community composition and temporal change at deep Gulf of Mexico cold seeps. Deep-Sea Research Part II: Topical Studies in Oceanography 57 (21-23), 1891-1903.

Lietard, C., Pierre, C., 2008. High-resolution isotopic records $\left(\delta^{18} \mathrm{O}\right.$ and $\left.\delta^{13} \mathrm{C}\right)$ and cathodoluminescence study of lucinid shells from methane seeps of the Eastern Mediterranean. Geo-Marine Letters 28 (4), 195-203.

Lietard, C., Pierre, C., 2009. Isotopic signatures $\left(\delta^{18} \mathrm{O}\right.$ and $\left.\delta^{13} \mathrm{C}\right)$ of bivalve shells from cold seeps and hydrothermal vents. Geobios 42 (2), 209-219.

Lorrain, A., Paulet, Y.-M., Chauvaud, L., Dunbar, R., Mucciarone, D., Fontugne, M., 2004. $\delta^{13}$ C variation in scallop shells: increasing metabolic carbon contribution with body size? Geochimica et Cosmochimica Acta 68 (17), 3509-3519.

MacAvoy, S.E., Macko, S.A., Carney, R.S., 2003. Links between chemosynthetic production and mobile predators on the Louisiana continental slope: stable carbon isotopes of specific fatty acids. Chemical Geology 201 (3-4), 229-237.

MacDonald, I.R., Sager, W.W., Peccini, M.B., 2003. Gas hydrate and chemosynthetic biota in mounded bathymetry at mid-slope hydrocarbon seeps: Northern Gulf of Mexico. Marine Geology 198 (1-2), 133-158.

McConnaughey, T.A., Burdett, J., Whelan, J.F., Paull, C.K., 1997. Carbon isotopes in biological carbonates: respiration and photosynthesis. Geochimica et Cosmochimica Acta 61 (3), 611-622. McConnaughey, T.A., Gillikin, D., 2008. Carbon isotopes in mollusk shell carbonates. GeoMarine Letters 28 (5), 287-299.

McCorkle, D.C., Keigwin, L.D., 1994. Depth profiles of $\delta^{13} \mathrm{C}$ in bottom water and core top $C$. wuellerstorfi on the Ontong Java Plateau and Emperor Seamounts. Paleoceanography 9 (2), 197208. 
Miyazaki, J.I., de Olivera Martins, L., Fujita, Y., Matsumoto, H., Fujiwara, Y., 2010. Evolutionary process of deep-sea Bathymodiolus mussels. PLoS ONE 5 (4), e10363.

Nix, E.R., Fisher, C.R., Vodenichar, J., Scott, K.M., 1995. Physiological ecology of a mussel with methanotrophic endosymbionts at three hydrocarbon seep sites in the Gulf of Mexico. Marine Biology 122 (4), 605-617.

Page, H.M., Fisher, C.R., Childress, J.J., 1990. Role of filter-feeding in the nutritional biology of a deep-sea mussel with methanotrophic symbionts. Marine Biology 104 (2), 251-257.

Powell, E.N., Barber, R.D., Kennicutt Ii, M.C., Ford, S.E., 1999. Influence of parasitism in controlling the health, reproduction and PAH body burden of petroleum seep mussels. Deep Sea Research Part I: Oceanographic Research Papers 46 (12), 2053-2078.

Prouty, N.G., Sahy, C.D., Ruppel, E.B., Condon, D., Brooke, S., Ross, S.W., Demopoulus, A.W.J., 2016. Insights into methane dynamics from analysis of authigenic carbonates and chemosynthetic mussels at newly-discovered Atlantic Margin seeps. Earth and Planetary Science Letters 449, 332-344.

Quay, P., Sonnerup, R., Westby, T., Stutsman, J., McNichol, A., 2003. Changes in the ${ }^{13} \mathrm{C} /{ }^{12} \mathrm{C}$ of dissolved inorganic carbon in the ocean as a tracer of anthropogenic $\mathrm{CO}_{2}$ uptake. Global Biogeochemical Cycles 17 (1), 1004.

Riekenberg, P.M., Carney, R.S., Fry, B., 2016. Trophic plasticity of the methanotrophic mussel Bathymodiolus childressi in the Gulf of Mexico. Marine Ecology Progress Series 547, 91-106.

Sassen, R., Joye, S., Sweet, S.T., DeFreitas, D.A., Milkov, A.V., MacDonald, I.R., 1999.

Thermogenic gas hydrates and hydrocarbon gases in complex chemosynthetic communities, Gulf of Mexico continental slope. Organic Geochemistry 30 (7), 485-497.

Romanek, C.S., Grossman, E.L., Morse, J.W. 1992. Carbon isotopic fractionation in synthetic aragonite and calcite: Effects of temperature and precipitation rate. Geochimica et Cosmochimica Acta 56 (1), 419-430.

Sassen, R., Roberts, H.H., Carney, R., Milkov, A.V., DeFreitas, D.A., Lanoil, B., Zhang, C., 2004. Free hydrocarbon gas, gas hydrate, and authigenic minerals in chemosynthetic communities of the northern Gulf of Mexico continental slope: relation to microbial processes. Chemical Geology 205 (3-4), 195-217.

Smith, E.B., Scott, K.M., Nix, E.R., Korte, C., Fisher, C.R., 2000. Growth and condition of seep mussels (Bathymodiolus childressi) at a Gulf of Mexico Brine Pool. Ecology 81 (9), 2392-2403. 
Solomon, E.A., Kastner, M., Jannasch, H., Robertson, G., Weinstein, Y., 2008. Dynamic fluid flow and chemical fluxes associated with a seafloor gas hydrate deposit on the northern Gulf of Mexico slope. Earth and Planetary Science Letters 270 (1-2), 95-105.

Spótl, C., Vennemann, T.W., 2003. Continuous-flow isotope ratio mass spectrometric analysis of carbonate minerals. Rapid Communications in Mass Spectrometry 17 (9), 1004-1006. Wanamaker, A.D., Kreutz, K.J., Borns, H.W., Introne, D.S., Feindel, S., Funder, S., Rawson, P.D., Barber, B.J., 2007. Experimental determination of salinity, temperature, growth, and metabolic effects on shell isotope chemistry of Mytilus edulis collected from Maine and Greenland. Paleoceanography 22 (2), n/a-n/a.

Weber, J.N., Woodhead, P.M.J., 1970. Carbon and oxygen isotope fractionation in the skeletal carbonate of reef-building corals. Chemical Geology 6, 93-117.

Wells, R.J.D., Rooker, J.R., 2009. Feeding ecology of pelagic fish larvae and juveniles in slope waters of the Gulf of Mexico. Journal of Fish Biology 75 (7), 1719-1732.

Acknowledgements. We thank J. Hipes for laboratory assistance, D. Feng for analysis of shell composition, and W.B. Stickle for helpful comments on an earlier version of this manuscript and service as a graduate committee member. Funding for the analyses provided by the Bureau of Ocean Energy Management contract M08AC2008. Original sampling of archive material was made possible by the considerable help of the vessel and submersible crews of Harbor Branch Oceanographic Institution.

Author contribution: PR prepared samples for laboratory analysis, assisted in analysis of the samples, undertook data analysis and wrote the manuscript. RSC planned the initial experimental design, undertook field work, maintained the archival collection, contributed to the data interpretation and assisted with statistical analysis and writing of the manuscript. BF undertook sample analysis, contributed to the data interpretation and assisted with statistical analysis and writing of the manuscript. The group of co-authors has approved the submission of this manuscript. 
Conflicts of interest: None 


\section{Figures}

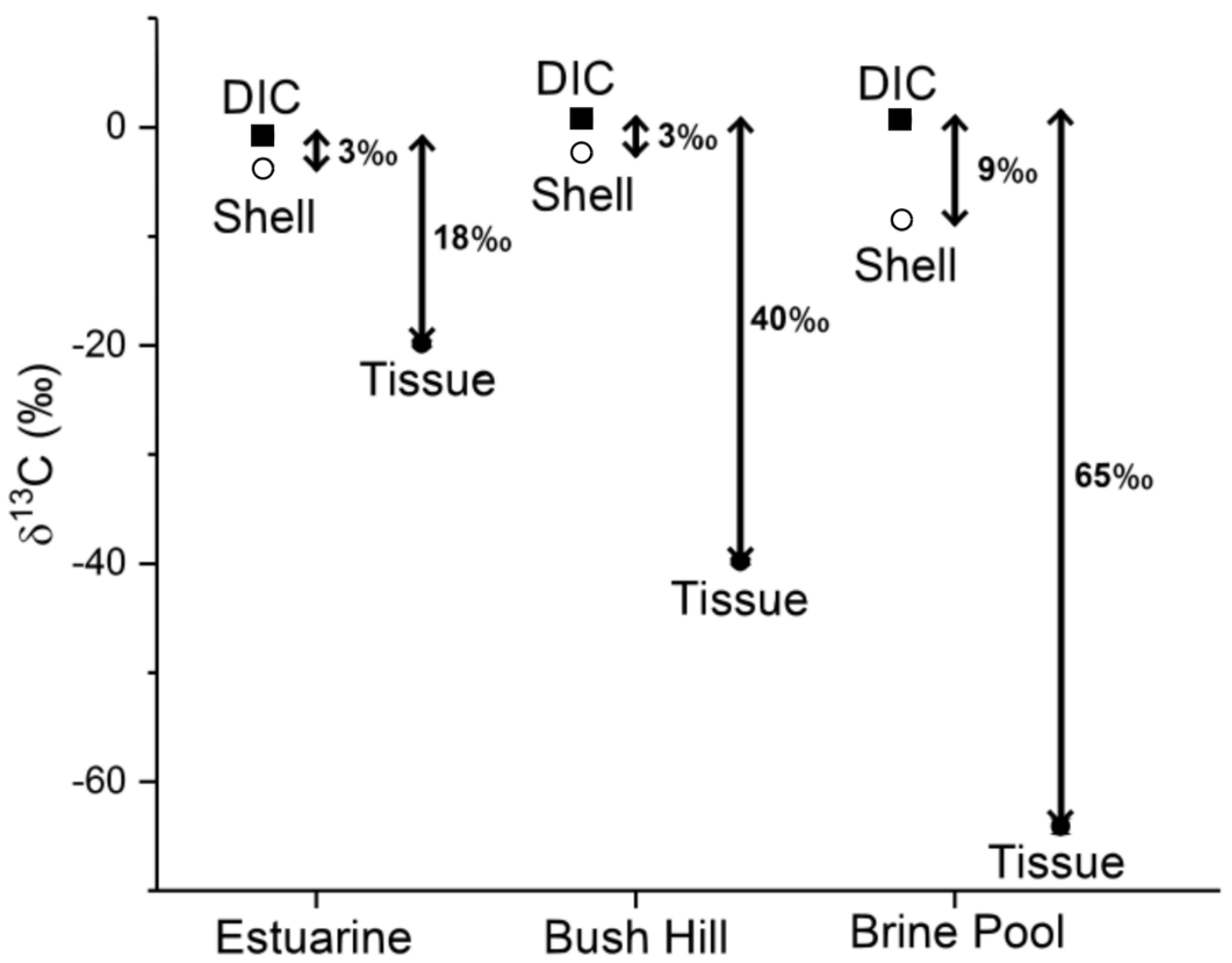

Figure 1: Comparison of $\delta^{13} \mathrm{C}$ ranges observed within estuarine and cold seep settings.

Estuarine shell and tissue values taken from Mercenaria mercenaria from Gilliken et al. (2007), with corresponding DIC $(-0.77 \pm 0.2 \%)$ represented by water from the sediment-water interface. Bathymodiolus childressi tissue and shell values for the respective cold seep sites are reported as mean \pm SE with most error bars too small to be seen due to the scale of the y-axis (80\%). DIC $(0.69 \%)$ for Bush Hill and Brine Pool was taken from ambient seawater collected at the sediment-water interface at Bush Hill from Fu et al. (1998). 


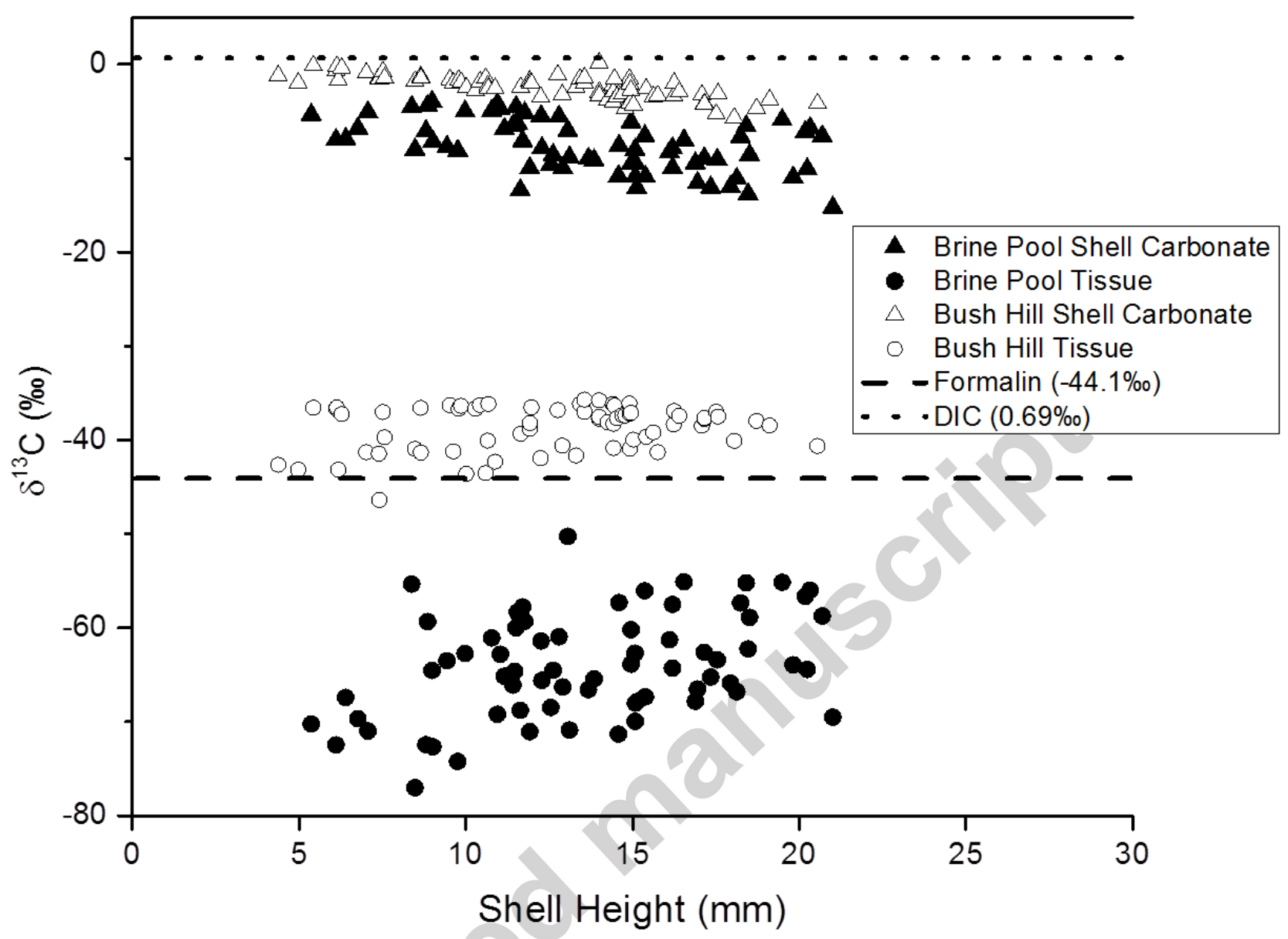

Figure 2: $\delta^{13} \mathrm{C}$ values for mussel shell and tissue plotted versus shell height. Lower $\delta^{13} \mathrm{C}$ values for both tissue and shell for the Brine Pool indicate reliance on local biogenic methane resources. Higher $\delta^{13} \mathrm{C}$ values at Bush Hill indicate reliance on local thermogenic methane resources. The dashed lines indicate $\delta^{13} \mathrm{C}$ values for seawater DIC and formalin. 


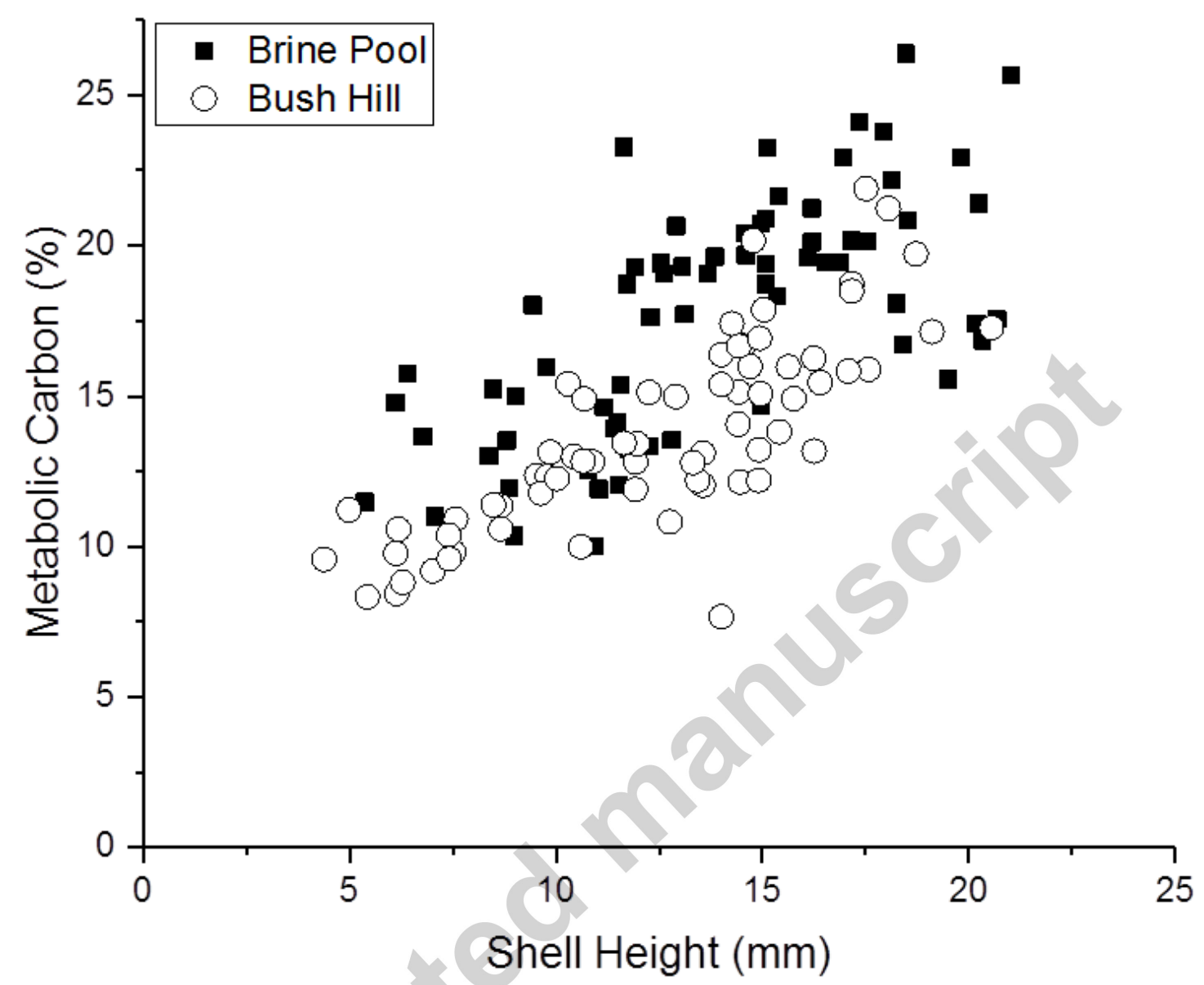

Figure 3: $\mathbf{C}_{\mathbf{m}}$ at each site plotted versus shell height. In the plot, no size correction has been applied to $C_{m}$. Average values at sites were $17.7 \pm 0.5 \% C_{m}$ and $13.6 \pm 0.5 \mathrm{~mm}$ shell height for $\mathrm{BP}$ and $13.7 \pm 0.4 \% \mathrm{C}_{\mathrm{m}}$ and $12.3 \pm 0.5 \mathrm{~mm}$ shell height for $\mathrm{BH}$. 


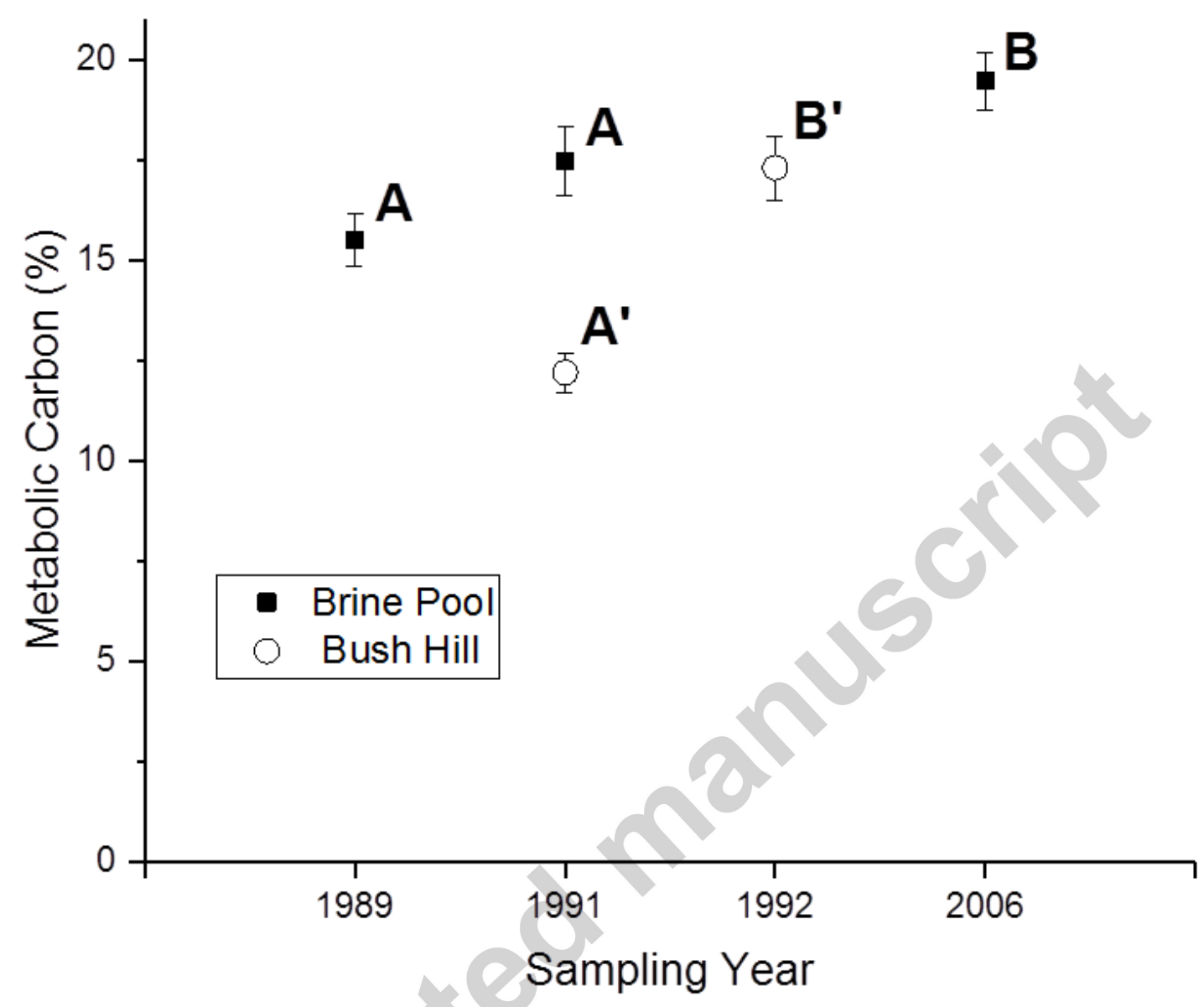

Figure 4: $C_{m}$ between sampling years. $C_{m}$ for both Brine Pool and Bush Hill for within sampling years at each site (mean $\pm \mathrm{SE}$ ). Letters indicate significant differences within sites between sampling years. 


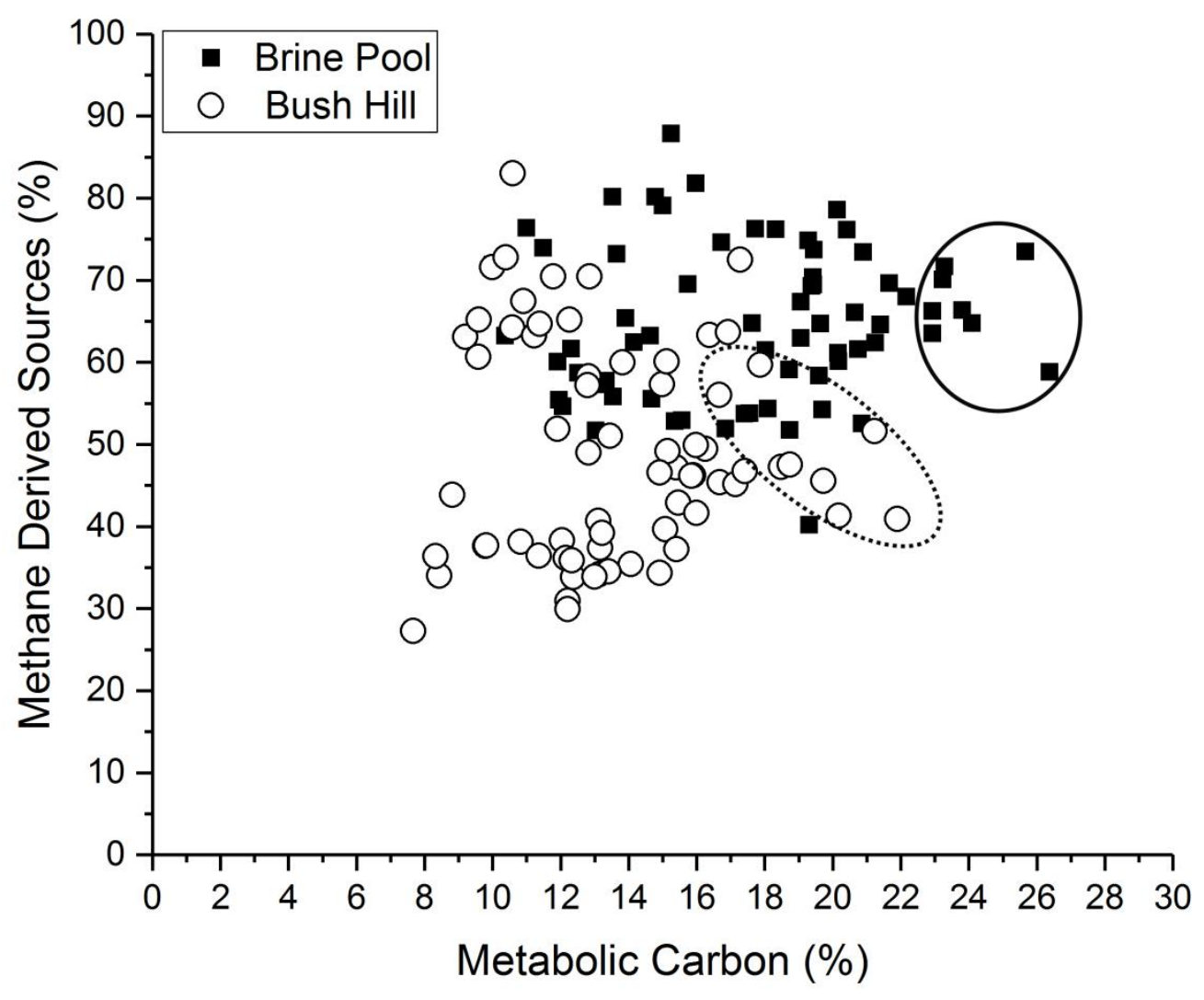

Figure 5: Percentage of diet of methane-derived resources versus metabolic carbon. Circled areas indicate samples that have the highest $\mathrm{C}_{\mathrm{m}}$ at both sites (BP, solid line; $\mathrm{BH}$, dotted line). 


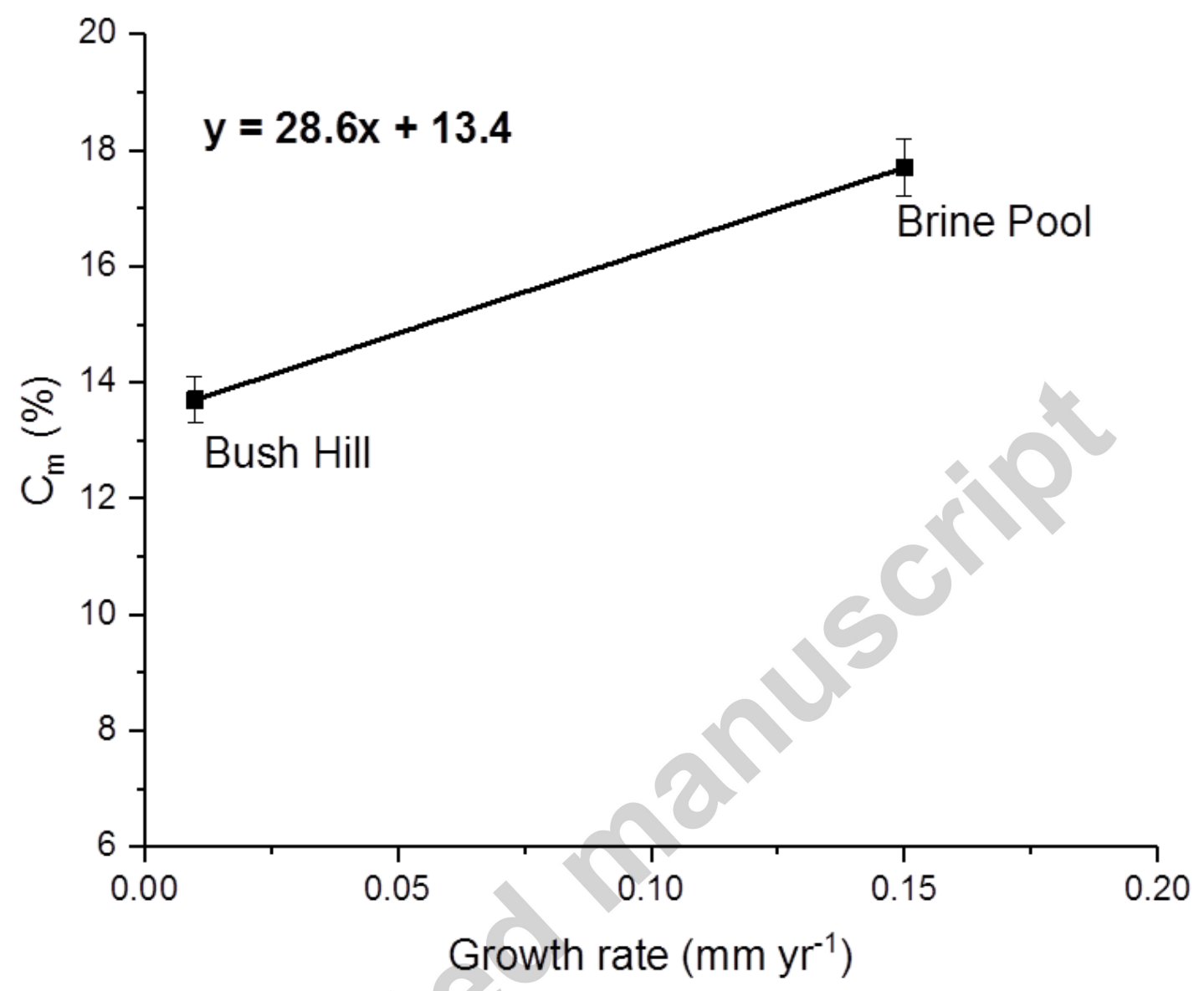

Figure 6: Metabolic carbon versus previously measured growth rates. The y intercept (13.4\%) of this relationship provides an estimate of the lower limit of methane derived resources for zero growth. Growth rates for Bush Hill and Brine Pool were calculated for B. childressi at each site using similar methods in both studies (Nix et al. 1995; Smith et al. 2000; respectively; mean \pm SE). 


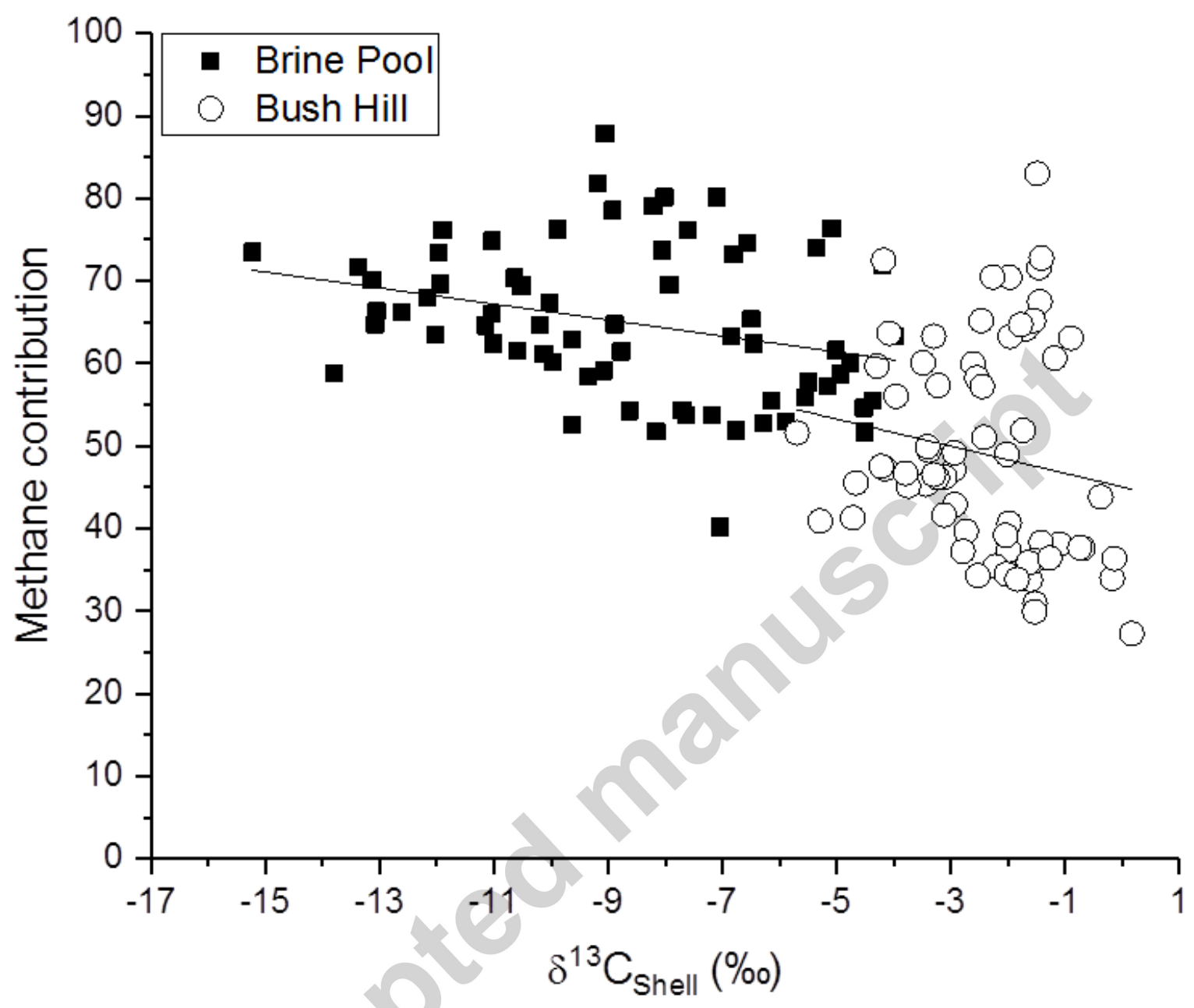

Figure 7: Percentage of diet from methane-derived resources versus $\delta^{13} \mathrm{C}_{\text {Shell. }}$. Linear regressions were used to investigate this relationship and found weak correlations for both sites despite the apparent negative relationship (BP, $y=-0.96+56.6, \mathrm{R}^{2}=0.08$; $\mathrm{BH}, \mathrm{y}=-1.65 \mathrm{x}+45.1, \mathrm{R}^{2}=0.03$ ). 


\section{Author's Accepted Manuscript}

Shell Carbon Isotope Indicators of Metabolic Activity in the Deep-Sea Mussel Bathymodiolus childressi

P.M. Riekenberg, R.S. Carney, B. Fry

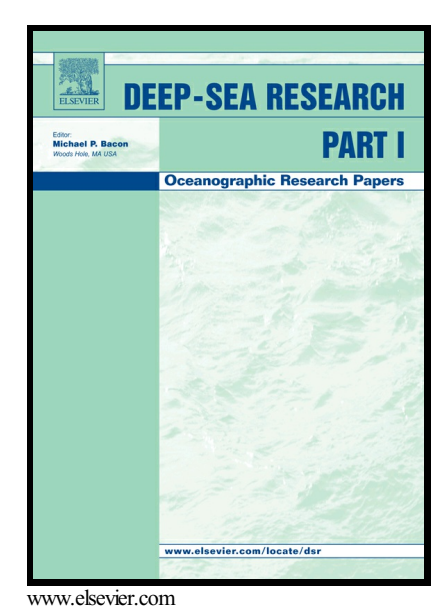

PII: $\quad$ S0967-0637(17)30345-X

DOI: $\quad$ https://doi.org/10.1016/j.dsr.2018.02.004

Reference: DSRI2881

To appear in: Deep-Sea Research Part I

Received date: 31 October 2017

Revised date: 19 February 2018

Accepted date: 26 February 2018

Cite this article as: P.M. Riekenberg, R.S. Carney and B. Fry, Shell Carbon Isotope Indicators of Metabolic Activity in the Deep-Sea Mussel Bathymodiolus childressi, Deep-Sea Research Part I, https://doi.org/10.1016/j.dsr.2018.02.004

This is a PDF file of an unedited manuscript that has been accepted for publication. As a service to our customers we are providing this early version of the manuscript. The manuscript will undergo copyediting, typesetting, and review of the resulting galley proof before it is published in its final citable form. Please note that during the production process errors may be discovered which could affect the content, and all legal disclaimers that apply to the journal pertain. 